\title{
Pelatihan Penerapan Pendekatan Saintifik Dalam Pembelajaran Untuk Guru Biologi SMA Di Kabupaten Gunungkidul, Yogyakarta
}

\author{
Training of Scientific Approach Application in the Learning \\ for Biology Teachers of Senior High School in Gunungkidul, Yogyakarta
}

Paidi*, Sukarni Hidayati, dan Atik Kurniawati

Jurusan Pendidikan Biologi, FMIPA, UNY, *Email: paidi@uny.ac.id

\begin{abstract}
Abstrak
Kegiatan PPM ini bertujuan untuk meningkatkan pemahaman guru-guru Biologi di Kabupaten Gunung Kidul, Yogyakarta untuk menerapkan pendekatan saintifik dalam pembelajaran. Pelaksanaan kegiatan PPM ini terdiri dari dua bagian, bagian pertama adalah penyampaian materi dan bagian kedua adalah penyusunan perangkat pembelajaran yang menerapkan pendekatan saintifik oleh peserta pelatihan. Metode yang digunakan dalam pelatihan meliputi metode ceramah dan tanya jawab, praktikum, kunjungan laboratorium, dan penugasan/latihan. Kegiatan ini diikuti oleh 16 guru mata pelajaran Biologi di Kabupaten Gunungkidul, Provinsi Daerah Istimewa Yogyakarta. Evaluasi pelaksanaan kegiatan PPM ini dilakukan dengan menyebarkan lembar respon pada peserta. Hasil lembar respon menunjukkan bahwa pelatihan tentang penerapan pendekatan saintifik dalam pembelajaran berjalan dengan lancar dan sesuai harapan. Hal ini diketahui dari respon peserta terhadap semua aspek masuk dalam kategori baik. Selain itu, antusias peserta dalam mengikuti setiap materi yang disampaikan tergolong bagus. Peserta aktif melakukan kegiatan praktek dan kegiatan kunjungan laboratorium untuk melihat contoh specimen yang tersedia.
\end{abstract}

Kata kunci: pendekatan saintifik

\begin{abstract}
This PPM (community service) program aimed at improving Biology teachers' understanding in applying scientific approach of learning in Gunung Kidul, Yogyakarta. The implementation of this program consisted of two parts. The first part was the delivery of the materials and the second was the preparation of learning tools and media based on scientific approach. The methods used in the training included lectures, question and answer methods, lab-work activities, laboratory visits, and giving assignment or exercises. There were sixteen Biology teachers in Gunungkidul, Yogyakarta who participated in this activity. The evaluation of PPM implementation was done by spreading the questionnaires to the participants. The results of questionnaires indicated that the training on the application of scientific approach in learning went smoothly and as expected. It was known from the participant's response to the questions which were categorized as good. Participants showed great enthusiasm in following the training and lecturing. In addition, they actively involved in practical activities and laboratory visits to see samples of available specimens.
\end{abstract}

Key words: scientific approach

\section{PENDAHULUAN}

Pendekatan saintifik (scientific approach) sering dianggap sebagai salah satu icon atau penciri Kurikulum 2013. Sebagian besar ahli dan praktisi pendidikan menangkap kesan bahwa, untuk semua jenjang pendidikan, untuk semua mata pelajaran, dan untuk semua $\mathrm{KD} /$ materi pelajaran, Kurikulum 2013 menekankan penggunaan pendekatan ini. 
Anggapan tersebut, tentu kurang pas, khususnya pada bidang sains. Pada bidang sains, termasuk biologi, pendekatan saintifik sudah direkomendasi penggunaannya sejak kurikulum 2006 dan bahkan kurikulumkurikulum sebelumnya. Pendekatan ini sudah diintroduksi penggunaannya sejak era Kurikulum tahun 1980an, sebagai pendekatan keterampilan proses (PKP), Pendekatan saintifik/merupakan pendekatan yang digunakan guru dalam pembelajaran, yang berbasis pada proses keilmuan. Pendekatan ini menggunakan prinsip metode ilmiah, seperti langkah-langkah para ilmuwan dalam menemukan fakta, konsep, atau produk keilmuan lainnya. Pendekatan ini mewarnai langkah aktivitas guru dan siswa dalam pembelajaran.

Dalam Permendikbud No. 103 tahun 2014 disebutkan bahwa pendekatan saintifik merupakan pengorganisasian pengalaman belajar dengan urutan logis meliputi 5 langkah proses pembelajaran. Kelima langkah tersebut meliputi (1) mengamati; (2) menanya; (3) mengumpulkan informasi/mencoba; menalar/mengasosiasi; dan

mengomunikasikan. Kelima langkah tersebut dikenal dengan "5M". Prinsipprinsip pembelajaran dengan pendekatan saintifik yang disebutkan dalam Permendikbud No. 81A tahun 2013 meliputi: berpusat pada peserta didik, mengembangkan kreativitas peserta didik, menciptakan kondisi menyenangkan dan menantang, bermuatan nilai, etika, estetika, logika dan kinestetika, serta menyediakan pengalaman belajar yang beragam melalui penerapan berbagai strategi dan metode pembelajaran yang menyenangkan, kontekstual, efektif, efisien dan bermakna. Sesuai rekomendasi Kurikulum 2013, guru Biologi pun menggunakan pendekatan saintifik atau $5 \mathrm{M}$ ini dalam pembelajaran Biologi. Keterampilan guru dalam menggunakan pendekatan saintifik ini menentukan keberhasilan pencapaian kompetensi.

Namun demikian, dari beberapa informasi, para guru, termasuk para guru biologi di Gunungkidul, belum seperti yang diharapkan. Para guru, baik di sekolah yang menerapkan Kurikulum 2006 maupun yang menerapkan Kurikulum 2013, pembelajaran yang diwarnai langkah-langkah ilmiah, seperti para ilmuwan dalam melakukan proses penemuannya, masih jauh dari harapan/yang seharusnya. Di beberapa kelas, proses pembelajaran yang mencoba menggunakan pendekatan saintifik, justru ditemukan ketidaksesuaian. Langkahlangkah mengamati, menanya, dan seterusnya, yang seharusnya sepenuhnya dilakukan siswa, justru dilakukan guru (sebagian atau keseluruhan). Di beberapa kelas yang lain, pembelajaran yang mencoba menggunakan pendekatan saintifik, berlangsung nyaris tanpa objek dan permasalahan yang relevan.

Kebelumsesuaian penggunaan pendekatan saintifik di Gunungkidul tersebut, salah satunya dimungkinkan akibat guru belum sepenuhnya memahami hakikat pendekatan saintifik dan penerapannya. Hal ini sesuai kesimpulan Sajidan (2014), dari hasil monitoring dan evaluasi yang dilakukan sejumlah pemonev, bahwa $81 \%$ guru di Indonesia masih mengharapkan pelatihan tentang konsep kurikulum (mind set), $80 \%$ guru mengharapkan pelatihan pembelajaran dengan metode saintifik dan $65 \%$ guru menghendaki adanya pelatihan penilaian dan penulisan rapor pada kurikulum 2013. Oleh karena itu, perlu adanya suatu pelatihan mengenai Kurikulum 2013, salah satunya adalah penggunaan pendekatan saintifik dalam pembelajaran.

Berdasarkan beberapa fakta dan permasalahan tersebut, maka program pengabdian pada masyarakat (PPM), untuk membentuk peningkatan pemahaman dan kesiapan guru dalam mengimplementasikan pendekatan saintifik dalam pembelajaran biologi SMA di Kabupaten Gunungkidul dipandang perlu dilakukan. Program PPM yang tidak saja fokus pada prinsip pendekatan saintifik, melainkan juga penyiapan media dan sumber belajar yang relevan ini, diharapkan mampu membekali para guru biologi di Kabupaten 
Gunungkidul meningkatkan kualitas pembelajaran biologi.

Diharapkan melalui pelaksanaan kegiatan pengabdian ini dapat meningkatkan pemahaman guru, khususnya guru Biologi di Kabupaten Gunungkidul, tentang prinsip dasar pendekatan saintifik dan penerapannya dalam pembelajaran biologi. Selain itu, diharapkan dapat meningkatkan keterampilan guru dalam menyusun rencana pembelajaran yang menerapkan pendekatan saintifik dan meningkatkan keterampilan guru dalam menyiapkan media dan sumber belajar pendukung pendekatan saintifik dalam pembelajaran, serta diharapkan dapat meningkat keterampilan guru dalam menggunakan media dan sumber belajar pendukung pendekatan saintifik.

\section{SOLUSI/TEKNOLOGI}

Pelaksanaan kegiatan PPM ini terdiri dari dua bagian, bagian pertama adalah penyampaian materi dan bagian kedua adalah penyusunan perangkat pembelajaran yang menerapkan pendekatan saintifik oleh peserta pelatihan. Metode yang digunakan dalam pelatihan meliputi metode ceramah dan tanya jawab, praktikum, kunjungan laboratorium, dan penugasan/latihan.

1. Metode ceramah dan tanya jawab digunakan untuk menyampaikan konsep-konsep Penerapan pendekatan saintifik dalam pembelajaran dan penyiapan serta penggunaan media bahan ajar yang diharapkan dapat dikuasai oleh peserta pelatihan. Pada saat penyampaian konsep, pemateri juga menyelingi dengan metode tanya jawab untuk menghimpun pengertian peserta terhadap materi sekaligus menghimpun pendapat peserta.

2. Metode Praktikum dilakukan setelah pemberian materi. Peserta melakukan praktek langsung mempraktekkan materi penyiapan dan pembuatan specimen Mikroorganisme di Lab. Mikrobiologi.

3. Metode Kunjungan Laboratorium dilakukan untuk memberi kesempatan pada peserta pelatihan untuk melakukan kunjungan ke Lab. Media Pendidikan Biologi dan Lab. Botani. Kunjungan ini bertujuan untuk mengobservasi specimen dan media pembelajaran yang tersedia pada lab tersebut.

4. Metode Penugasan/Latihan digunakan untuk memberikan tugas kepada peserta untuk menyusun Rencana Pelaksanaan Pembelajaran (RPP) yang menerapkan pendekatan saintifik serta materi-materi yang diperoleh saat pelatihan.

Materi pelatihan yang disampaikan pada peserta terdiri dari 4 materi pokok. Keempat materi tersebut adalah sebagai berikut:

1. Prinsip dasar pendekatan saintifik dan penerapannya dalam pembelajaran biologi di SMA, oleh Dr. Paidi, M.Si

2. Penyiapan dan Penggunaan Media dan Bahan Ajar dalam bentuk Spesimen Mikroorganisme untuk mendukung Penerapan Pendekatan Saintifik dalam Pembelajaran Biologi oleh: Anna Rakhmawati, M.Si.

3. Penyiapan dan Penggunaan Media dan Bahan Ajar dalam bentuk Spesimen dan Non Spesimen untuk mendukung Penerapan Pendekatan Saintifik dalam Pembelajaran Biologi oleh: Surahman, M.S.

4. Sanctioning hasil penyiapan media dan sumber belajar dan rencana penerapannya dalam pembelajaran, oleh Dr. Paidi, M.Si.

Kegiatan ini diikuti oleh 16 guru mata pelajaran Biologi di Kabupaten Gunungkidul, Provinsi Daerah Istimewa Yogyakarta.

\section{HASIL DAN DISKUSI}

Kegiatan PPM "Pelatihan Penerapan Pendekatan Saintifik dalam Pembelajaran untuk Guru Biologi SMA di Kabupaten Gunung Kidul, Yogyakarta" diawali dengan penyampaian rencana kegiatan kepada ketua MGMP Biologi Kabupaten Gunungkidul dan dilanjutkan dengan pengiriman undangan program pelatihan kepada 22 guru Biologi Kabupaten Gunungkidul di FMIPA 
UNY. Jumlah guru yang diundang dalam kegiatan pengabdian ini adalah 22 guru, yang aktif di MGMP mata pelajaran biologi di Kabupaten Gunungkidul. Dari 22 guru yang diundang, 16 orang yang memenuhi undangan dan datang pada saat pelaksanaan pelatihan tersebut.

Kegiatan pelatihan diawali dengan penyampaian materi. Setelah penyampaian materi, kegiatan pelatihan diakhiri dengan pembagian Lembar respon peserta terhadap pelaksanaan pelatihan yang telah diikuti. Tujuan pembagian instrumen ini adalah untuk memperoleh gambaran global bagaimana pendapat peserta terhadap pelatihan baik materi maupun potensi untuk diaplikasikan dalam pembelajaran, apakah termasuk dalam kategori sangat baik (4), baik (3), kurang baik (2), atau sangat kurang baik (1). Hasil respon semua peserta dapat dilihat pada Tabel 2.

Tabel 2. Respon Peserta terhadap Pelaksanaan Pelatihan

\begin{tabular}{|c|c|c|c|}
\hline No. & Aspek & $\begin{array}{l}\text { Rata-Rata } \\
\text { Respon } \\
\text { Peserta }\end{array}$ & Kategori \\
\hline 1. & $\begin{array}{l}\text { Penyampaian } \\
\text { Materi } 1\end{array}$ & 3.5 & Baik \\
\hline 2. & $\begin{array}{l}\text { Substansi } \\
\text { Materi } 1\end{array}$ & 3.4 & Baik \\
\hline 3. & $\begin{array}{l}\text { Penyampaian } \\
\text { Materi } 2\end{array}$ & 3.6 & Baik \\
\hline 4. & $\begin{array}{l}\text { Substansi } \\
\text { Materi } 2\end{array}$ & 3.5 & Baik \\
\hline 5. & $\begin{array}{l}\text { Aplikasi dalam } \\
\text { pembelajaran }\end{array}$ & 3.5 & Baik \\
\hline 6. & $\begin{array}{l}\text { Akomodasi } \\
\text { Pelatihan }\end{array}$ & 3.3 & Baik \\
\hline
\end{tabular}

Hasil tersebut menunjukkan bahwa pelatihan tentang penerapan pendekatan saintifik dalam pembelajaran berjalan dengan lancar dan sesuai harapan. Hal ini diketahui dari respon peserta terhadap keenam aspek yang ditanyakan, terlihat pada Tabel 2. Peserta pelatihan menunjukkan respon yang baik untuk semua aspek dengan angka respon berkisar 3,3-3,6 atau masuk kategori baik. Respon maksimal yang dapat diberikan peserta adalah 4 dengan kategori sangat baik. Respon peserta pada saat kegiatan terlihat baik. Hal ini dilihat dari antusias peserta dalam mengikuti setiap materi yang disampaikan. Peserta aktif melakukan kegiatan praktek dan kegiata kunjungan laboratorium untuk melihat contoh specimen yang tersedia.

Keterlaksanaan pelatihan ini didukung oleh berbagai faktor. Faktorfaktor pendukung tersebut adalah sebagai berikut:

1. Penyebaran undangan pelaksanaan pelatihan melalui jaringan MGMP Guru Biologi SMA Kabupaten Gunungkidul DIY, sehingga memudahkan penyampaian informasi agenda pelaksanaan pelatihan.

2. Peserta memiliki minat yang tinggi terhadap materi yang disampaikan terlihat pada semangat/antusias peserta saat kegiatan pelatihan.

3. Pemilihan tempat pelaksanaan kegiatan pelatihan yaitu Lab Biologi yang tersedia alat-alat yang digunakan untuk kegitan praktek peserta dan berbagai contoh spesimen yang dapat diamati oleh peserta pelatihan. Selain itu, tempat pelatihan sudah diketahui oleh peserta, sehingga memudahkan peserta menuju lokasi.

Sebaliknya, penyelenggaraan kegiatan pelatihan ini juga menghadapi beberapa kendala yang disebabkan oleh faktorfaktor penghambat. Faktor-faktor penghambat tersebut adalah sebagai berikut:

1. Komunikasi dengan perwakilan peserta terkait tema yang cukup memakan waktu.

2. Jarak antara lokasi pelaksanaan kegiatan pelatihan dengan lokasi sekolah tempat peserta tinggal/bertugas tergolong sehingga tidak semua guru dapat memenuhi undangan yang telah disebar.

3. Keterbatasan waktu pelaksanaan kegiatan pelatihan karena mempertimbangkan jarak lokasi 
pelatihan dengan daerah asal peserta yang terhitung jauh.

\section{KESIMPULAN}

Kegiatan pelatihan ini secara umum dapat meningkatkan meningkatkan pemahaman guru-guru Biologi di Kabupaten Gunung Kidul, Yogyakarta untuk menerapkan pendekatan saintifik dalam pembelajaran.

\section{UCAPAN TERIMA KASIH}

Keterlaksanaan kegiatan PPM melibatkan banyak pihak baik yang mendukung dengan berbagai bantuan baik bantuan fisik maupun non-fisik. Oleh karenanya, ucapan terima kasih ditujukan kepada Dekan Fakultas Matematika dan Ilmu Pengetahuan Alam Universitas Negeri Yogyakarta, Ketua Jurusan dan Kaprodi Pendidikan Biologi FMIPA UNY, Ketua dan pengurus MGMP Guru Biologi SMA Kabupaten Gunungkidul, atas bantuan komunikasi dan distribusi informasi dari Tim PPM ke peserta dan sebaliknya, dan Para guru Biologi SMA Kabupaten Gunungkidul, DIY atas peran aktifnya dalam kegiatan PPM

\section{PUSTAKA}

Bugbee, B. 2003. Nutrient management in recirculating hydroponik culture. Paper presented at The South Pacific Soil-less Culture Conference, Feb 11, 2003 in Palmerston North, New Zealand
Chow, V. 1990. The Commercial approach in hydroponics. International Seminar on Hydroponic Culture of High Value Crops in the Tropics in Malaysia, November 25-27, 1990.

Del Rosario, A. Dafrosa, and P.J.A. Santos. 1990. Hydroponic culture of crops in the Philippines: Problems and prospect. International Seminar on Hydroponic Culture of High Value Crops in the Tropics in Malaysia, November 25-27, 1990.

Jensen, M.H. 1990. Hydroponic culture for the tropics: Opportunities and alternatives. International Seminar on Hydroponic Culture of High Value Crops in the Tropics in Malaysia, November 25-27, 1990.

Marvel, M.E. 1974. Hydroponic culture of vegetable crops. University of Florida, Gainesville, Florida.

Raffar, K.A. 1990. Hydroponics in tropica. International Seminar on Hydroponic Culture of High Value Crops in the Tropics in Malaysia, November 25-27, 1990.

Rosliani dan Sumarni, 2005. Budidaya Tanaman Sayuran dengan Sistem Hidroponik 